УДК 347.73

DOI https://doi.org/10.32838/2707-0581/2019.5/25

Komziuk V.L.

Taras Shevchenko National University of Kyiv

\title{
SOME ISSUES OF IMPLEMENTATION OF BASEL STANDARDS INTO BANKING LEGISLATION OF UKRAINE
}

The author of this article has studied the state regulation of banking activity in Ukraine in the context of the implementation of Basel III requirements into banking legislation of Ukraine. The Basel Committee on Banking Supervision (the "BCBS") of the Bank of International Settlements (the "BIS") adopted and updates Basel standards as universal minimal requirements to banking activity aimed at creation of "level-playing field" among different jurisdictions.

The Basel Committee on Banking Supervision in response to the financial crisis of 2007-2008 issued a third set of recommendations on the resilience of banks and financial systems, called Basel III in 2011. Despite the fact that Basel III is an instrument of "soft law", that is, it is not binding, member states of the committee are adapting national legislation to Basel's requirements.

Basel III has been implemented into European Union legislation like the so-called Capital Requirements Directive IV package, comprising EU Directive 2013/36/EU and EU Regulation 575/2013. This approach allows for effective regulation of banking activity using two mechanisms. First, the EU Regulation establishes mandatory rules that can be directly applied as part of national law. Second, the EU Directive lays down the general principles and provisions which must be implemented in the national legislation of the EU Member States. Countries are free to determine the specific forms and methods of implementing directives into national law.

As Ukraine has committed itself to adapt its own legislation, including banking regulation, to European Union law, and Basel III has, in fact, become part of EU law, de facto Ukraine must also implement Basel III requirements in national law.

The article also evaluates the functioning of some issues of banking law in Ukraine.

Key words: Basel III, Basel committee, banking regulation, implementation, National bank of Ukraine.

Problem statement. Ukraine has declared numerous times its decision to aim for the European Union (the EU) membership. In doing so, the parliament enacted the "National program of adaptation of the legislation of Ukraine to the legislation of the EU" (the National Adaptation Program) in 2004. Followed by the "Association Agreement between Ukraine, on the one hand, and the European Union, the European Atomic Energy Community, and their Member States, on the other" (the Association Agreement) signed in 2014, two documents outline obligations and commitments of Ukraine to adapt national legislation to acquis communautaire (Acquis).

The Basel Committee on Bank Supervision (the BCBS) implemented a series of documents aimed at the creation of a level-playing field in banking regulation between different jurisdictions, commonly referred to as Basel Accords of Basel principles. While it is a soft law framework mechanism (i.e. does not create legal obligations to the parties) and Ukraine is not a member of BCBS, Basel Accords are considered a "best practice" requirements and were also implemented in Acquis.

Considering Ukraine opted for EU association and banking legislation is one of the priority fields of the National Adaptation Program, Basel standards shall be implemented in Ukrainian banking legislation.

Analysis of recent research and publications. Numerous publications are dedicated to the analysis of the so-called Basel III, the latest Basel Accord, but the implementation of Basel III into Ukrainian banking legislation was left behind by the researchers. General issues related to the implementation of Basel accords into Ukrainian legislation were researched by F. Heid, A. Kashyap and J. Stein, D. Kerwer, C. Schenk, and others, V. Prykhodko. K. Rozhkova, O. Selezniova, and others.

Implementation of Basel III worldwide or in foreign jurisdictions and general regulatory changes related to Basel accords were researched by Schenk C., Heid. F., Kashyap A., Stein J., Kerwer D., Jenkinson N., Wilson C., Ferreira C., Guerra-Martinez A., Remolina N. 
The purpose of the article is to develop recommendations on the implementation of Basel III accord into Ukrainian legislation.

Main research results. As a response to a series of financial crises in banking and financial industries, a group of eleven countries (Belgium, Canada, France, Germany, Italy, Japan, Netherlands, Sweden, Switzerland, Great Britain and USA) established the BCBS to "enhance financial stability by improving the quality of banking supervision worldwide, and to serve as a forum for regular cooperation between its member countries on banking supervisory matters" and to "... close gaps in international supervisory coverage so that (i) no banking establishment would escape supervision; and (ii) supervision would be adequate and consistent across member jurisdictions" [1].

Basel regulatory framework emerged as a response to fluctuations in international banking and financial markets at the end of 1974. Risky behavior of national banks and financial companies caused negative global externalities [1]. In particular, Bankhaus Herstatt in Germany failed to execute money transfers in deposit returns and swap operations after receiving payments from its counterparts. Time zone differences between Germany and the USA led to settlement problems as the regulator started Bankhaus Herstatt bankruptcy procedure after the bank received the money transfer, but before it made a corresponding money transfer (Catherine R. Schenk, 2011) [2].

Bankhaus Herstatt bankruptcy, Lugano crisis and IBB collapse in London (and series of less discussed difficulties) resulted in the establishment of the Committee on Banking Regulations and Supervisory Practices (now called The Basel Committee on Banking Supervision or Basel Committee) based in the Bank for International Settlements in Basel.

Basel committee adopted three sets of recommendations on banking regulation usually referred to as Basel Accords. The "International convergence of capital measurement and capital standards" [3] dated 1988 (with later amendments of 1995) was the first one and focused on credit risk and risk weighting of assets. Overall assessment of Basel I is positive as it created a benchmark of banking sector regulation worldwide. Despite some drawbacks, central ideas of Basel I were implemented in more than 100 countries and often apply to national banks either.

Basel I framework was aimed to "...serve to strengthen the soundness and stability of the international banking system..." and "...to have a high degree of consistency in its application to banks in different countries intending to diminishing an existing source of competitive inequality among international banks" [3, intro. 3].

While Basel II accord was focused on changes in the previous framework, it had an important goal of promoting "the greater use of assessments of risk provided by banks' internal systems as inputs to capital calculations" [4]. This step was the first one towards reliance on internal bank information and models to calculate risks; thus it laid the foundations of Basel III accord. Nevertheless, Basel II was criticized for having pro-cyclical effects [5] or failure to mitigate procyclicality of the bank capital (inefficiency in this part) [6].

Ability to absorb shocks and avoid negative spillovers from banking crises to real economy thus was the primary objective of Basel III [7]. In doing so, Basel III focuses on "improving the banking sector's ability to absorb shocks arising from financial and economic stress" [7] as well as "improving risk management and governance as well as strengthen banks' transparency and disclosures" [7, intro 2].

Implementation of Basel III, however, faces risks as much stricter rules face the opposition of the banking sector and country authorities. While trying to make banking and financial markets safer, it imposes high capital requirements on banks thus making profits shrink. Besides, banks fear that implementation of the Basel III requirements will "trap capital that could be better deployed elsewhere" [8].

Despite the fact that Basel III is not implemented yet, market insiders already talk about the next steps in financial regulation. McKinsey\&Company published a report [9] assessing proposed changes to a current regulatory framework (ones implemented already and upcoming) and how banks should react to it.

The other thought is with all the changes and amendments existing regulation, in fact, is the new framework already. PWC developed some solutions and approaches for banks to adapt to new requirements already. According to PWC "Basel IV encompasses more than just finalizing Basel III - According to many bank representatives, the requirements of the Basel Committee have expanded so much in recent years that we must already start referring to Basel IV" [10].

As Basel III is implemented by the EU and Ukraine pledged to adapt the national legislation to the Acquis, the approximation of national legislation and Basel Accords is required.

Acquis is a broad definition of the legal system of the EU that includes primary and secondary legislation of EU, court decisions and soft law. The legislation includes, among other things, EU directives, regulations, decisions and opinions of the Court of Justice. 
In the EU, Basel III was partially implemented already in so-called Capital Requirements Directive IV package, comprising Directive 2013/36/EU [11] and Regulation (EU) No 575/2013 [12]. While the EU Regulation has general application, are binding in their entirety and directly applicable in all European Union countries, EU Directives are not directly applicable and must be transposed in national legislation of member states [13, Art. 288].

The Directive 2013/36/EU contains general guidelines for the member states regarding, among other issues, designation and powers of the competent authorities, coordination within member states, cooperation within the European System of Financial Supervision and specific policy issues. EU Member states amend national legislation in the way its regulatory effect will satisfy the general requirements of the Directive 2013/36/EU.

The Regulation (EU) No 575/2013 applies directly and regulates the behavior of credit institutions or investment firms. Its provisions are specific, have restrictive meaning and the same effect as provisions of the national legislation.

Such a two-tier approach (i.e. setting specific compulsory rules and general guidelines) allows to create a consistent, but minimal regulatory field between different jurisdictions. At the same time, countries are free to amend national legislation in the most suitable way to reflect the requirements of the Directive 2013/36/EU. This approach is useful as banking and financial markets may significantly vary between jurisdictions and Basel Accords, as well as Capital Requirements Directive IV package only intend to create baseline regulation instead of replacing national regulations.

The Basel regulatory framework and its implementation comprise a multi-level system, that allocates different powers and enforcement procedures. The first level - Basel Accords itself are a mechanism of soft law. The BCBS drafts Basel Accords and amendments thereto, but issues official documents only upon discussion with central bank governors of G10 countries. Even though decisions and documents issued by the BCBS are not binding, they represent a "best-practice" type of standards and are typically adopted by national governments. One of the main reasons non-binding standards are successful is because they work better with regulatory autonomy of states than binding documents [14].

The second level is supra-national implementation, limited to the EU member countries. Such a layer is appropriate as EU countries have a single market, including the market for financial services. It comprises two-level regime consisting of direct effect Regulation and general guidelines Directive.

On the third level, the EU Member countries draft specific regulations that in a way more suitable for individual countries. As regulators are the ones most aware of country-specific data, such regulation (affected by the Regulation and Directive) is most effective.

In Ukraine, the regulation of banking and financial markets is three-tier and not unified. The first level is general and special banking legislation. General legislation includes all laws that set out general principles for banking (e.g., the Law of Ukraine "On Financial Services and State Regulation of Financial Services Markets"). Such laws do not directly regulate banking but do address some of its aspects. Special legislation directly regulates the banking market. It mainly includes the Law of Ukraine "On the National Bank of Ukraine" and the Law of Ukraine "On Banks and Banking Activity".

The second level consists of by-laws, which are issued based on laws and directly regulate banking activities by specifying legislative requirements. Although regulations are issued based on laws and should not contradict them, they set specific rules that have a significant impact on banking and financial markets.

The third level is formed by the official interpretations and recommendations of the authorities, which explain and specify the issues of application of legislative norms. They typically have an action-oriented nature and highly specific.

The state executes regulatory influence on banking and financial markets through authorized bodies, mainly - the National Bank of Ukraine. It exercises banking regulation, which consists of "the establishment of a system of rules governing the activities of banks, defining general principles of banking activity, the procedure for conducting banking supervision, responsibility for violation of banking regulations". In addition to rulemaking, the NBU also carries out banking supervision, that means "the control and actions of the National Bank of Ukraine aimed at ensuring compliance by banks and other companies under supervision of the National Bank of Ukraine of legislation of Ukraine, established requirements in order to ensure stability of the banking system and protect the interests of clients and creditors of banks". Thus, the NBU powers are not limited to supervision of banks, but also envisages rulemaking.

The NBU started implementing Basel III as part of the 2020 Complex program for the development 
of the financial sector of Ukraine, adopted by the NBU in 2015 ("Program 2020"). Program 2020 was supplemented by the decision of the NBUs Board "On approval of action plan for the implementation of EU legislation aimed at implementation of the Association Agreement" [15].

According to Program 2020, the NBU implements Basel standards as a measure to create prerequisites for the sustainable development of the financial sector. In practice, the NBUs' aim is (1) to strengthen requirements to solvency and liquidity of market actors by means of introduction of new requirements to capitalization, solvency, liquidity of banks and (2) to follow new principles of bank supervision envisaged by Basel III [16].

Implementation of Basel III into the banking legislation of Ukraine started in 2015. The NBU amended the Instruction on the procedure of banking regulation in Ukraine (the "Instruction") [17]. The regulator introduced scheduled requirements and regulations that became effective in 2019 or were scheduled to become effective in 2020. Such amendments concern introduction of conservation, countercyclical and systemic importance capital buffers, additional requirements for systematically important banks, and amended system of limits of operations with affiliated companies.

The approach of delayed enforcement of new requirements was specifically picked by the NBU to decrease negative effects and provide time buffer (1.5 to 2 years) for banks to adjust their business models [18].

Subsequently, the NBU amended the Instruction and NBU Resolution "On the incorporation of credit risk in the calculation of capital ratios by banks" [19] in 2017. Such amendments have "...specified that banks shall define credit exposure ... to recognize uncovered credit risk when calculating regulatory capital", excluded "loan loss provisions against asset operations of the 1 st quality category as a component of Tier 2 capital", "disregarded long-term liquidity gaps from the calculation of the regulatory capital adequacy ratio", "provided that a zero credit risk-weighted will be applied to all the assets under transactions with international financial institutions ... and used in the calculation of regulatory capital adequacy ratio" and "unified the rules governing the calculation of credit risk ratios (H7, H9) for specialized savings banks" according to the statement of the NBU [20].

In 2017, the NBU presented its approach to the implementation of Basel requirements in three priority levels. First, immediate introduction of new requirements to risk assessment of banks and introduction of stress-tests aimed at the evaluation of individual banks' resilience. Second, gradual introduction of new requirements to internal control systems of banks and to handling non-performing assets. Third, introduction of new capital structure and requirements to coverage of operational and market risks, introduction of leverage coefficient both scheduled for 2019-2020 [21].

In 2018, the NBU introduced a new instrument of capitalization that allows conversion or write-off designated as a loss absorption mechanism [22] and introduced liquidity coverage ration and made minor changes to list of highly liquid assets [23].

The NBU stressed that some requirements of Basel III will not be implemented in Ukraine in the foreseeable future as they are too complex for the national system [24]. Such an approach is considered appropriate by the researchers and international organization. C. Ferreira in IMF working paper states that "...it may make sense to prioritize some elements depending upon country-specific factors, e.g., risk profile, supervisory capacity, etc" [25, p. 33].

The multi-level regulation of banking and financial markets, the high quantity of by-laws and broad discretionary powers of the regulator complicate the implementation of Basel standards in the banking legislation of Ukraine. In addition to the broad discretion of the NBU, IMF researchers point out some weaknesses that are typical for regulators in most countries. Such weaknesses include "inappropriate institutional setting, lack of skilled resources, insufficient forward-looking analysis, lax credit risk standards, inappropriate liquidity risk standards and monitoring, weak corporate governance, and weak enforcement" $[25$, p. 8].

Researchers point out, that the Basel regime is not the universal cure for all jurisdictions. Most countries have different financial systems with different problems, priorities of regulators, market structures, economic implications of higher capital requirements. Also, the regulatory regime was introduced by developed countries with strong financial markets. They face different problems and obstacles comparing with developing countries [26, p. 147-149].

In addition, the Basel regime itself is not constant. Some market insiders point out that already present amendments to Basel III create specifically new and stronger regulatory regime. It will require banks to take unconventional measures and raise more capital than anticipated. As these amendments are massive, they are referred to as Basel IV [9]. 
Both issues require regulators to analyze Basel III against the needs of the domestic financial system. It means, that the NBU should avoid mimicking EU regulation and focus on achieving same result, rather than implementing same legal provisions.

One of the mechanisms that simplify the implementation of the Basel standards is the codification of banking legislation. Ukrainian researchers have repeatedly emphasized the expediency of codification of legislation in order to avoid contradictions in regulation and conflicting provisions [27, p. 31; 27, p. 59]. Codification of banking legislation may be simultaneously combined with the implementation of Basel standards. Potential benefits from the codification of banking legislation require additional research.

Considering the commitments of Ukraine to adapt its legislation to Acquis, it is useful to study further the experience of the EU Member states in the adaptation of national legislation to Basel III and adoption of EU Directive and Regulation aimed at fulfillment of Basel III requirements.

BCBS conducts semiannual studies of implementation of Basel III requirements in member jurisdictions and has recently published a sixteenth progress report on the adoption of the Basel regulatory framework [29]. BCBS examines current state of Basel III implementation among member countries in four stages: (1) draft regulation not published, (2) draft regulation published, (3) final rule published, and (4) final rule in force. As some provisions of Basel III will take effect from 2022, the implementation is still in progress.

Conclusions. Basel regulatory regime intends to create a consistent regulation of banking activity among developed jurisdictions. In doing so it promotes unified approaches to regulation, introducing minimal requirements and standardized approaches to banking regulation. Implementation of Basel III standards in Ukrainian legislation will increase the stability of the national banking system, level of trust to banks and international cooperation with multinational banks and international financial institutions.

Both the Basel regulatory regime and Ukrainian banking legislation are complex and multi-level. Successful implementation of Basel standards in Ukrainian banking legislation shall be supplemented with the analysis and systematization of Ukrainian legislation.

\section{References:}

1. History of the Basel Committee. URL: https://www.bis.org/bcbs/history.htm (дата звернення: 25.09.2019).

2. Schenk C. Summer in The City: The 1974 international banking crisis in London and its implications for regulatory reform. URL : http://www.erim.eur.nl/fileadmin/erim_content/documents/1974_Crisis_and_ Response_15_Nov.pdf (дата звернення: 25.09.2019).

3. International Convergence of Capital Measurement and Capital Standards (1988). URL : https://www.bis. org/publ/bcbs04a.pdf (дата звернення: 25.09.2019).

4. International Convergence of Capital Measurement and Capital Standards: A Revised Framework (June 2004). Intro. 6. URL : https://www.bis.org/publ/bcbs107.pdf. (дата звернення: 25.09.2019).

5. Heid F. (2003). Is regulatory capital pro-cyclical? A macroeconomic assessment of Basel II (preliminary version). URL : https://www.bis.org/bcbs/events/wkshop0303/p05heid.pdf (дата звернення: 25.09.2019).

6. Kashyap A. and Stein J. (2003). Cyclical Implications of the Basel-II Capital Standards. URL : http://finra. complinet.com/net_file_store/new_rulebooks/f/s/FSA_basel-final.pdf (дата звернення: 25.09.2019).

7. Basel III: $\overline{\mathrm{A}}$ global regulatory framework for more resilient banks and banking systems (December 2010 (rev June 2011). Intro 1. URL : https://www.bis.org/publ/bcbs189.pdf (дата звернення: 25.09.2019).

8. Bother over Basel: Basel 3, an international capital-adequacy standard, is unloved but much needed (Special Report). URL : https://www.economist.com/news/special-report/21721497-international-bank-regulationgrinding-towards-completionor-possibly-halt-basel-3 (дата звернення: 25.09.2019).

9. Basel "IV": What's next for banks? Implications of intermediate results of new regulatory rules for European banks. URL : http://www.mckinsey.com/ /media/mckinsey/business\%20functions/risk/our\%20 insights/basel $\% 20 \mathrm{iv} \% 20$ whats $\% 20$ next $\% 20$ for $\% 20$ european $\% 20$ banks/basel-iv-whats-next-for-banks.ashx (дата звернення: 25.09.2019).

10. Basel IV; The next generation of RWA. URL : https://www.pwc.com/gx/en/services/advisory/basel-iv.html (дата звернення: 25.09.2019).

11. Directive 2013/36/EU of the European Parliament and of the Council of 26 June 2013 on access to the activity of credit institutions and the prudential supervision of credit institutions and investment firms, amending Directive 2002/87/EC and repealing Directives 2006/48/EC and 2006/49/EC. URL : https://eur-lex.europa.eu/ legal-content/EN/TXT/?uri=celex\%3A32013L0036 (дата звернення: 25.09.2019).

12. Regulation (EU) No 575/2013 of the European Parliament and of the Council of 26 June 2013 on prudential requirements for credit institutions and investment firms and amending Regulation (EU) No 648/2012. URL : https:/eur-lex.europa.eu/legal-content/en/TXT/?uri=celex\%3A32013R0575 (дата звернення: 25.09.2019). 
13. Treaty on the Functioning of the European Union. Art. 288. URL : https://eur-lex.europa.eu/legal-content/ EN/TXT/?uri=celex\%3A12012E\%2FTXT (дата звернення: 25.09.2019).

14. Kerwer D. Rules that Many Use: Standards and Global Regulation. Governance. 2005. 18(4). P. 611-632.

15. Впровадження нових вимог до капіталу відповідно до норм Базеля та законодавства EC. URL : https://bank.gov.ua/doccatalog/document?id=47725151 (дата звернення: 25.09.2019). https://bank.gov.ua/ doccatalog/document?id=73007243.

16. Комплексна програма розвитку фінансового сектору україни до 2020 року. URL : https://bank.gov.ua/ doccatalog/document?id=73007243 (дата звернення: 25.09.2019).

17. Про затвердження Змін до Інструкції про порядок регулювання діяльності банків в Україні : Постанова Національного банку України від 12.05.2015 p. № 312. URL : https://zakon5.rada.gov.ua/laws/show/ v0312500-15 (дата звернення: 25.09.2019).

18. Рожкова К. Плани щодо гармонізації законодавства України та $Є C$ для банківського і фінансового сектора. URL : http://consulting.colocall.com/files/download/Rozhkova\%20Ukr.pdf (дата звернення: 25.09.2019).

19. Про затвердження Положення про порядок формування та зберігання обов'язкових резервів банками України та філіями іноземних банків в Україні : Постанова Національного банку України від 11.12.2014 p. № 806. URL : https://zakon.rada.gov.ua/laws/show/v0806500-14 (дата звернення: 25.09.2019).

20. The National bank of Ukraine amends the instruction on the procedure of banking regulation in Ukraine. URL : https://bank.gov.ua/control/en/publish/article?art_id=44099839 (дата звернення: 25.09.2019).

21. Рожкова К. Плани щодо гармонізації законодавства України та ЄС для банківського і фінансового сектора. URL : http://consulting.colocall.com/files/download/Rozhkova\%20Ukr.pdf (дата звернення: 25.09.2019).

22. Національний банк запроваджує новий інструмент капіталізації банків. URL : https://bank.gov.ua/ news/all/natsionalniy-bank-zaprovadjuye-noviy-instrument-kapitalizatsiyi-bankiv (дата звернення: 25.09.2019).

23. Національний банк змінив розрахунок нормативу миттєвої ліквідності. URL : https://bank.gov.ua/ news/all/natsionalniy-bank-zminiv-rozrahunok-normativu-mittyevoyi-likvidnosti (дата звернення: 25.09.2019).

24. Національний банк провів традиційну нараду з топ-менеджерами найбільших банків України. URL: https://bank.gov.ua/control/uk/publish/article?art_id=78326069\&cat_id=55838 (дата звернення: 25.09.2019).

25. Ferreira C., Jenkinson N., Wilson C. From Basel I to Basel III: Sequencing Implementation in Developing Economies. URL : https://www.imf.org/en/Publications/WP/Issues/2019/06/14/From-Basel-I-to-Basel-IIISequencing-Implementation-in-Developing-Economies-46895 (дата звернення: 25.09.2019).

26. Gurrea-Martínez A, Remolina N. The Dark Side of Implementing Basel Capital Requirements: Theory, Evidence, and Policy. Journal of International Economic Law. 2019. Vol. 22 (1). P. 125-152.

27. Селезньова О. Функції кодифікації банківського законодавства України: онтологія поняття та пропозиції щодо класифікації. Юридична Україна. 2008. № 6. С. 31-35.

28. Приходько В. П. Кодифіковані закони як вид загальних банківських законів. Правовий вісник Української академії банківської справи. 2008. № 1. С. 58-61.

29. Sixteenth progress report on adoption of the Basel regulatory framework. Basel Committee on Banking Supervision (May 2019). URL : https://www.bis.org/bcbs/publ/d464.pdf (дата звернення: 25.09.2019).

\section{КОМЗЮК В.Л. ДЕЯКІ ПИТАННЯ ІМПЛЕМЕНТАЦІЇ БАЗЕЛЬСЬКИХ СТАНДАРТІВ ДО БАНКІВСЬКОГО ЗАКОНОДАВСТВА УКРАЇНИ}

Автор статті досліджував регулювання банківської діяльності в Україні в контексті імплементачії положень Базельських стандартів у законодавство України. Базельський комітет із банківського нагляду Банку міжнародних розрахунків прийняв та періодично оновлює стандарти мінімальних регуляторних вимог до банківської діяльності, спрямовані на створення рівних умов регулювання в різних юрисдикціях.

Базельський комітет із банківського нагляду у відповідь на фінансову кризу 2007-2008 рр. видав у 2011 р. третій набір рекомендацій щзодо стійкості банків та фінансових систем, який називають Базель III. Незважаючи на те, щчо Базель III є інструментом "м'якого права», тобто не є обов'язковим до виконання, краӥни - члени комітету адаптують наџіональне законодавство до вимог Базелю.

Базель III було імплементовано в законодавство Європейського Союзу через Директиву ЄС № 2013/36/EU та Регламент СС № 575/2013. Такий підхід дозволяє досягнути ефективного регулювання банківської діяльності через двамеханізми. Перший: Регламент СС встановлюєобов'язкові до виконання норми права, які можуть безпосередньо застосовуватися як частина наџіонального законодавства. Другий: Директива СС встановлює загальні принципи та положення, які необхідно імплементувати в 
начіональне законодавство країн - членів СС. Краӥни вільні у визначенні конкретних форм та способів імплементачії положень директив у національне законодавство.

Оскільки Украӥна взяла на себе зобов'язання адаптувати власне законодавство, в тому числі законодавство про регулювання банківськоїдіяльності, до законодавства Європейського Союзу, а Базель III фактично став частиною законодавства СС, де-факто Україна також повинна імплементувати вимоги Базеля ІІІ в начіональне законодавство.

У статті розглядаються також окремі питання функціонування банківського законодавства в Україні.

Ключові слова: Базель ІІІ, Базельський комітет, банківське регулювання, імплементація, НБУ. 